\title{
CORRIGENDUM \\ Revised biochronology of the Lower Cambrian of the Central Iberian zone, southern Iberian massif, Spain - CORRIGENDUM
}

JENSEN, S., PALACIOS, T., \& MARTÍ MUS, M.

doi:10.1017/S0016756809990677, Published online by Cambridge University Press 12 Feb 2010.

In the abstract and caption to Figure 6a of the above publication (Jensen, Palacios \& Martí Mus, 2010), 'Rusophycus isp.' should read 'Rusophycus cf. avalonensis'.

\section{Reference}

Jensen, S., Palacios, T. \& MARTí Mus, M. 2010. Revised biochronology of the Lower Cambrian of the Central Iberian zone, southern Iberian massif, Spain. Geological Magazine doi:10.1017/S0016756809990677. 